\title{
Temperature verification method of solar heat gains in installations with flat plate solar collectors - case study
}

ABSTRACT: Solar collectors are used increasingly in single-family housing. Their popularity depends on many factors, including the price-to-productivity ratio, which in turn results from the development of solar collector technology as well as entire systems. This development consists of many aspects, including those related to the modernization of control systems and measuring of solar collector systems. Currently used systems offer, among others, the ability to determine the approximate solar heat gains using the sensors necessary for normal control of the sensor system. The paper analyzes, on the example of one facility, how such installations work in Polish conditions. An installation consisting of 3 solar collectors has been selected for analysis, supporting the preparation of hot utility water for a single-family residential building. The detailed analysis concerned days with high heat gains compared to the average heat demand for hot water preparation in the building. The temperature verification method (TVM) of the calculated solar heat gains by the solar system controller has been proposed. Then, differences in measurements according to two methods (controller and TVM) have been presented at various characteristic moments of the installation's operation (start-up, stop) and during continuous operation. It has been shown that during the day gains measured by the controller can be $15 \%$ lower than gains measured by the TVM method. The check has been

$\triangle$ Corresponding Author: Piotr Olczak; e-mail: olczak@min-pan.krakow.pl

1 Mineral and Energy Economy Research Institute of the Polish Academy of Sciences, Kraków, Poland; ORCID iD: 0000-0002-4926-0845; e-mail: olczak@min-pan.krakow.pl

2021. The Author(s). This is an open-access article distributed under the terms of the Creative Commons Attribution-ShareAlike International License (CC BY-SA 4.0, http://creativecommons.org/licenses/by-sa/4.0/), which permits use, distribution, and reproduction in any medium, provided that the Article is properly cited. 
carried out at a daily sunlight value higher than $4.8 \mathrm{kWh} / \mathrm{m}^{2}$ measured on a horizontal plane. The ratio of heat energy supplied to the domestic hot water storage tank to the measured insolation has been $34 \%$. The sum of annual solar heat gains measured by the controller and TVM differed by $5.2 \%$.

KEYwORDS: measurement, solar energy, solar heat sources, energy efficiency measures, thermal solar collector

\section{Introduction}

In Poland, the development of renewable energy sources, including thermal solar collectors, has been observed for years (Knapik 2018; Olczak et al. 2020a). The most popular solar collectors used in Poland are Flat Plate Collector (FPC) and Evacuated Tube Collector (Olek et al. 2016) (in 2018 the total capacity of installed FPCs was $1.24 \mathrm{GW}$ and ETCs was $0.34 \mathrm{GW}$ (Weiss and Spörk-Dür 2018)). Installations consisting of them are made for ecological purposes (Jeleński et al. 2020) including in the fight against low emissions (Kryzia and Pepłowska 2019; Olczak et al. 2019; Olczak and Olek 2016) as well as for economic purposes (Olczak and Kryzia 2016a) and increasing energy security (Mirowski and Sornek 2015). The popularity of their use depends on forms of support (e.g. grants) as well as increased productivity (Baccoli et al. 2018; Figaj et al. 2019).

The potential of solar collectors to produce clean thermal energy using nanofluids has been experimentally tested by Sarafaz et al. (Sarafraz et al. 2019). Similar experiments for two types of collectors (Flat-Plate Collector and Evacuated Tube Collector) have been carried out by Lee et al. (Lee et al. 2020). Many studies focus on the concentration of solar radiation (Baccoli et al. 2018; Dayamand et al. 2020; Figaj et al. 2019; Olczak et al. 2017a,b; Olczak and Kryzia 2016b), especially low-radiation (Ocłoń et al. 2020) as well as to obtain the waste heat, which can be utilized for various purposes. This paper presents the model of the radiator used for photovoltaic (PV. Montoya-Márquez and Flores-Prieto analyzed the Heat Removal Factor and tilt angle for the flat plate collector (Montoya-Márquez and Flores-Prieto 2018). Katsaprakakis and Zidianakis optimized the cooperation of solar collectors with a biomass heater, using as a criterion the minimization of the cost of heat energy production at an increased level (Katsaprakakis and Zidianakis 2019). The Effect of the Inclination Angle on the Flat Plate Solar Collector Efficiency (in a Medium-Temperature) was investigated by Montoya-Marquez and Flores-Prieto (Montoya-Marquez and Flores-Prieto 2017). Fiaschi et al. conducted research on solar energy accumulation in Thermo-Electric Energy Storage (Fiaschi et al. 2019).

In order to check the installation effectivity, productivity of the installations are usually measured by one of many methods (exact or simplified one). The choice of estimation of installation's work effects may contribute to the available values of aggregated results in the form of 
thermodynamic, economic, ecological efficiency (Olczak et al. 2020b). In installations, especially micro and small, it is pointless from an economic point of view to use advanced measures of work gains and especially available solar radiation (Porzuczek 2016). In turn, the use of at least simplified measures is sometimes dictated by subsidy considerations for installations. The work focuses on the issue of operation of installations with solar collectors working in a single-family house located in Lesser Poland to support the preparation of domestic hot water. This issue mainly concerns checking the heat gains, which are measured by a controller with the option of a heat meter. Selected aspects of the operation of this installation have been raised in previous works concerning heat losses from the solar tank and economics surface changes, as well as frame use (Olczak 2020a, b). Al-Shamani et al. designed a $1.2 \mathrm{kWp}$ roof top grid-connected photovoltaic thermal system with $\mathrm{SiC}$ nanofluid that supply both electricity and hot water (water-based PVT) (Al-Shamani et al. 2017).

There are no solutions in the literature estimating the level of accuracy of calculating solar heat gains in a simplified form, i.e. without additional costs for the user of small installations consisting of solar collectors.

\section{Research object}

The solar installation has been chosen as the test object, the main element of which are 3 flat collectors (Fig. 1, Table 1). In addition to the collectors, the installation also includes a storage tank, a circulation pump with accessories as well as automation and piping. The collectors have been placed on the roof of the building at an angle of $30^{\circ}$ to the horizontal plane and face south-west (in relation to the roof plane, SW azimuth). Piping between collectors and domestic hot water tank are corrugated steel pre-insulated pipes (13 $\mathrm{mm}$ thick insulation). They contain about $8 \mathrm{dm}^{3}$ Solar Heat Fluid (SHF, Ergolid A $-20^{\circ} \mathrm{C}$ ), the basic properties of which are listed in Table 2. The entire installation with collectors and coils in the tank holds about $20 \mathrm{dm}^{3} \mathrm{SHF}$.

The analysis was carried out in the period from June 1, 2014 to May 31, 2015, the total incremental solar heat gains are shown in Figure 2. The total annual heat productivity (calculated at the inlet to the hot utility water tank) per absorber area was $287 \mathrm{kWh} / \mathrm{m}^{2}$.

Days (May 19-20, 2015) with high solar heat gains compared to the average heat demand for hot water preparation (amounting to $7.3 \mathrm{kWh} /$ day) (Olczak et al. 2015) have been selected for detailed analysis. At that time no other heat sources for hot water preparation except solar collectors' installation have been used. 


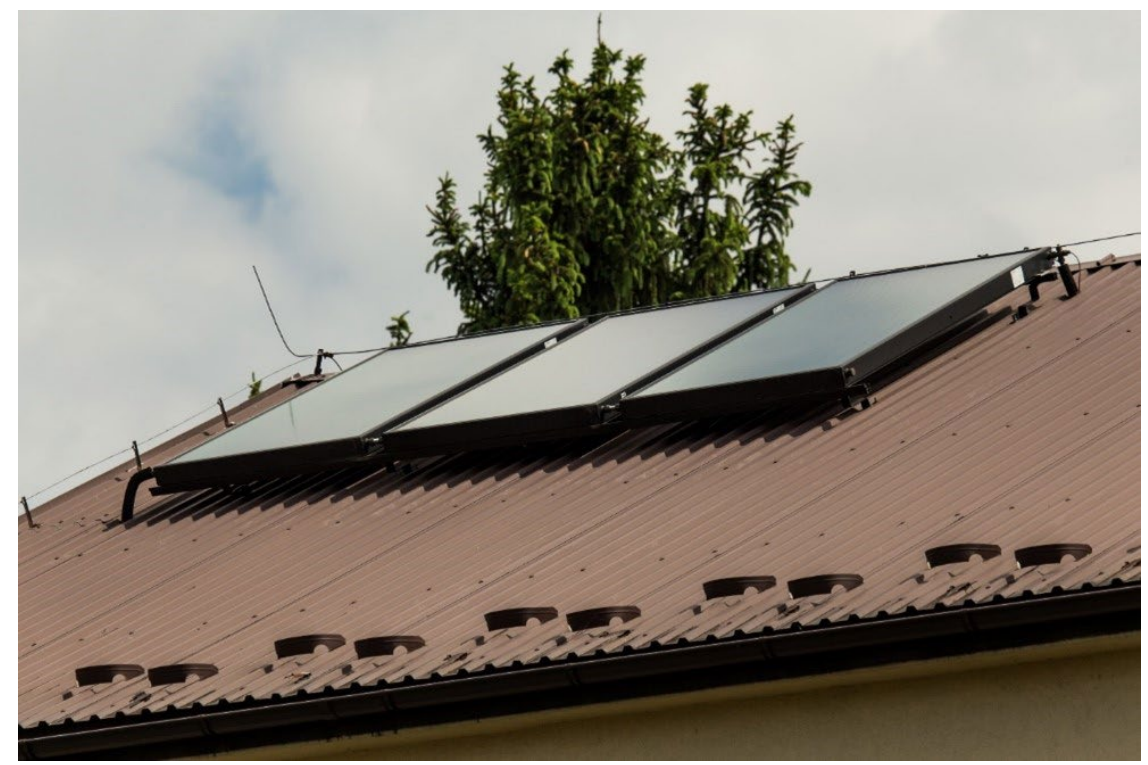

Fig. 1. The flat plate collector installation in detached house Source: own study

Rys. 1. Instalacja płaskich kolektorów słonecznych w budynku jednorodzinnym

TABLE 1. Basic parameters of the FPC in the installation

TABela 1. Podstawowe parametry FPC w instalacji

\begin{tabular}{|l|c|c|}
\hline \multicolumn{1}{|c|}{ Parameter } & Unit & Value \\
\hline Gross collector area & $\mathrm{m}^{2}$ & 2.07 \\
\hline Absorber area (Aa) & $\mathrm{m}^{2}$ & 1.87 \\
\hline Total Absorber area & $\mathrm{m}^{2}$ & 5.61 \\
\hline Structure (shape of collector)/flow pattern & & harp \\
\hline Intercept efficiency (for absorber area) & $\%$ & 0.751 \\
\hline Heat loss coefficient $\left(a_{1}\right)$ & $\mathrm{W} /\left(\mathrm{m}^{2} \cdot \mathrm{K}\right)$ & 4.999 \\
\hline Non-linear heat loss coefficient $\left(a_{2}\right)$ & $\mathrm{W} /\left(\mathrm{m}^{2} \cdot \mathrm{K}^{2}\right)$ & - \\
\hline Inlet flow rate per absorber area & $\mathrm{kg} /\left(\mathrm{h} \cdot \mathrm{m}^{2}\right)$ & 67.4 \\
\hline Slope of solar collector & $\circ$ & $30^{\circ}$ towards South-West \\
\hline
\end{tabular}

Source: own study based on (Biawar 2015). 
TABLE 2. Difference between water and Ergolid A -20C properties

TABELA 2. Różnice pomiędzy właściwościami wody a płynem Ergolid

\begin{tabular}{|l|c|c|c|}
\hline \multicolumn{1}{|c|}{ Parameter } & Unit & Water & SHF (Ergolid A -20C) \\
\hline Density & $\mathrm{kg} / \mathrm{dm}^{3}$ & 1.0 & 1.052 \\
\hline Specific heat & $\mathrm{kJ} /(\mathrm{kg} \cdot \mathrm{K})$ & 4.18 & 3.63 \\
\hline
\end{tabular}

Source: own work based on (Boryszewerg 2020).

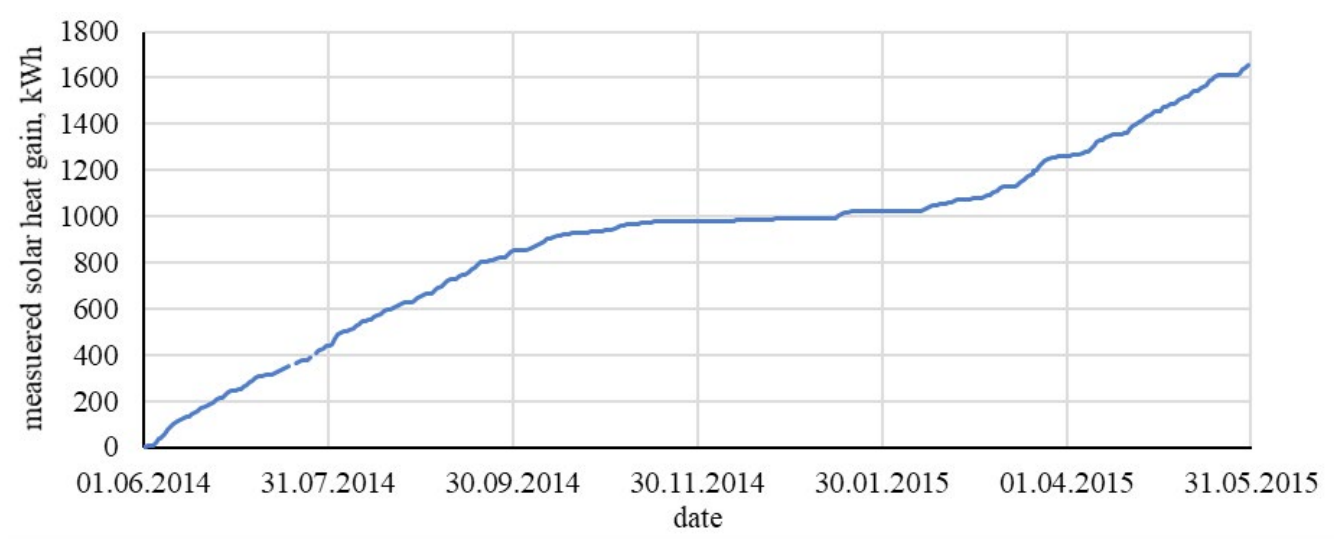

Fig. 2. Incremental solar heat gains 1.06.2014-31.05.2015

$$
\text { Source: own study }
$$

Rys. 2. Narastające solarne uzyski ciepła 1.06.2014-31.05.2015

\section{Measurement of the installation}

The amount of heat supplied from solar collectors to the hot water tank is calculated by the PLUM controller, which is equipped with a heat meter option (an additional T4 sensor has been added compared to the standard construction of the installation). The results are shown on the display (manual reading only) in the form of increasing values of heat supplied $\left(Q_{S}, \mathrm{kWh}\right)$. This device calculates solar heat gains using the equation:

$$
\dot{Q}_{S}(\tau)=(T 1(\tau)-T 4(\tau)) \cdot c_{S H F} \cdot\left(\dot{V} \cdot \rho_{F} \cdot \frac{1}{60}\right) \cdot P_{P}(\tau)
$$


where:

$\dot{Q}_{S} \quad-$ energy gains calculated by the controller,

$T 1(\tau)$ - temperature of the fluid flowing out of the solar collectors in $\tau$ time, recorded by PLUM,

$T 4(\tau)$ - return temperature from the hot water tank to the collectors in $\tau$ time, recorded by PLUM,

$C_{S H F}-$ specific heat of the fluid (from Table 2),

$\dot{V}-$ SHF flow rate maximum $\left(6 \mathrm{dm}^{3} / \mathrm{min}\right)$,

$\rho_{\mathrm{SHF}}-$ density of SHF (from table no 2 ) $\left[\mathrm{kg} / \mathrm{dm}^{3}\right]$,

$P_{p}(\tau)$ - current pump power in $\tau$ time related to maximum power, recorded by PLUM,

$\tau \quad-$ time.

During the solar installation operation, calculations are carried out in the controller according to the following assumption: the reduction in mass flow is proportional to the reduction in the circulation pump power. In case of blocking the possibility of the circulation pump power regulation, the above equation is simplified to following form:

$$
Q_{S}(\tau)=(T 1(\tau)-T 4(\tau)) \cdot c_{S H F} \cdot\left(V \cdot \rho_{F} \cdot \frac{}{60}\right)
$$

or

$$
\left\{\begin{array}{c}
\dot{Q}_{S}(\tau)=(T 1(\tau)-T 4(\tau)) \cdot c_{S H F} \cdot 0.1052, \text { when the pump works } \\
\dot{Q}_{S}(\tau)=0, \text { when the pump doesn't work. }
\end{array}\right.
$$

The calculation method implemented by the manufacturer in the controller is associated with certain inaccuracies mainly associated with:

$\downarrow$ not considering linear heat losses on the pipeline over a distance of approx. $15 \mathrm{~m}$ (from the outlet from the collectors to the entrance to the hot water tank) - this is related to the location of the $T 1$ sensor (Fig. 3),

$\checkmark$ the visual method of reading the maximum flow value from the flow meter $\left(6 \mathrm{dm}^{3} / \mathrm{min}\right)$. Other aspects affecting solar heat gains measurements are:

$\checkmark$ the dependence of the specific heat of the fluid from its temperature (applies to $\mathrm{c}_{\mathrm{SHF}}$ ),

$\checkmark$ dependence of fluid density from temperature - refers to the volumetric flow of fluid,

$\checkmark$ dependence of fluid viscosity from temperature and change of pipeline resistance characteristics and non-linear dependence of pump performance depending on electric power.

For the needs of the installation's research, additional temperature meters $\left(T 1^{\prime}, T 2^{\prime}, T 4^{\prime}, \mathrm{THI}\right)$ were installed in May 2015. The diagram of the installed devices at the solar hot water tank is shown in Figure 3. The system operation characteristics are influenced by the set value dT_on $=9 \mathrm{~K}$ and dT_off $=7 \mathrm{~K}$, i.e. the temperature difference measured between $T 1$ and $T 2$ responsible for switching the circuit on and off. Both values have been set by the installation designer. 


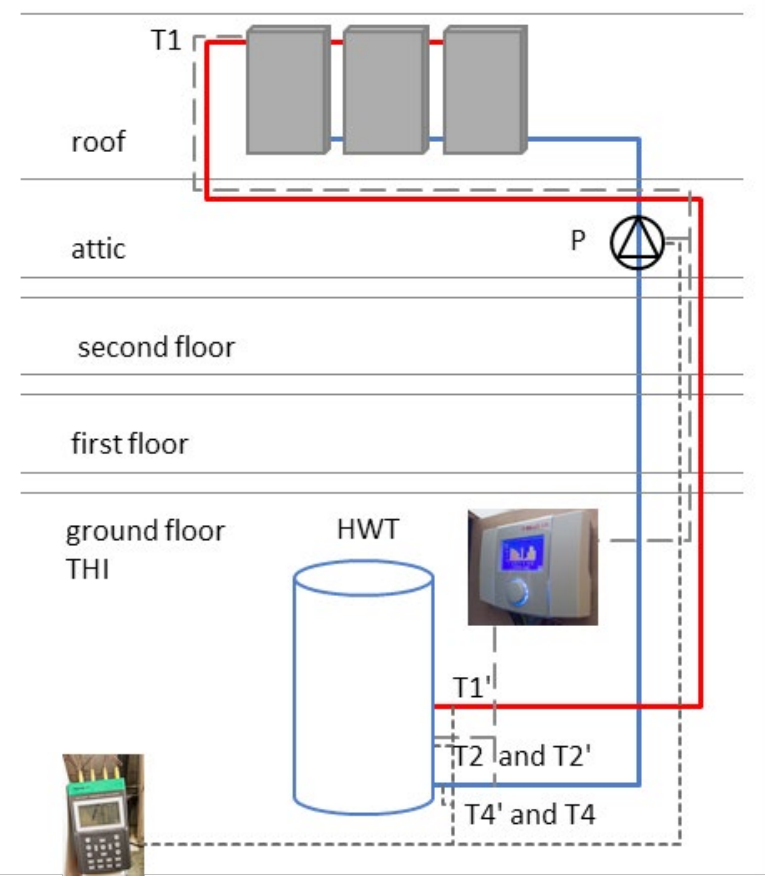

Fig. 3. Solar installation scheme with metering

Source: own study

Rys. 3. Schemat instalacji wraz z opomiarowaniem

\section{Research methods}

For the purposes of the study, the possibility of regulating the circulation pump power has been blocked. As a result, the pump has been running on-off. By using additional temperature meters, verifying the measurements of heat gains from the installation based on the following equation has been possible (author's TVM method) (modification of equation 2):

$$
\dot{Q}_{S T}(\tau)=\left(T 1^{\prime}(\tau)-T 4^{\prime}(\tau)\right) \cdot c_{S H F} \cdot\left(\dot{V} \cdot \rho_{F} \cdot \frac{1}{60}\right)
$$

where:

$\dot{Q}_{S T}-$ solar heat gains calculated by using temperature and flow rate meter [kW],

$T 1^{\prime} \quad-$ DHW tank flow temperature by solar installation in time $\tau\left[{ }^{\circ} \mathrm{C}\right]$, 

place as sensor $T 4\left[{ }^{\circ} \mathrm{C}\right]$

or

$$
\left\{\begin{array}{c}
\dot{Q}_{S T}(\tau)=\left(T 1^{\prime}(\tau)-T 4^{\prime}(\tau)\right) \cdot c_{S H F} \cdot 0.1052, \text { when the pump works } \\
\dot{Q}_{S T}(\tau)=0, \text { when the pump doesn't work }
\end{array}\right.
$$

In order to determine the available solar energy obtainable by the installation, the intensity of solar radiation incident on the vertical plane has been measured at a distance of several meters from the solar collectors. The measurements have been made with an EPLAB Pyranometer (Eplab), measuring the radiation band $(295-2800 \mathrm{~nm})$ with an accuracy class $(2 \%)$ - Figure 4 (EPLAB 2015). Obtained solar radiation density $(G)$ values allowed, among others, to select the periods when the pump had been running:

$\checkmark$ receiving heat currently produced from collectors,

$\checkmark$ receiving heat stored in collectors (not from current solar radiation), such cases may occur, for example, in the evening with a simultaneous decrease in temperature $T 2 / T 2^{\prime}$ in the tank. This situation has been observed among others for installations several times larger than the tested one (Olczak and Zabagło 2015).

Data has been collected every 10 seconds. Weather data (with an hourly frequency) for the days selected for analysis in the form of external temperature (TA) for the nearest weather station (Tarnów) has been downloaded from the ogimet.com weather service. The system had been diagnosed to determine the operating time of the circulating pump, which should be included in the calculation of solar gains (equation no. 4).

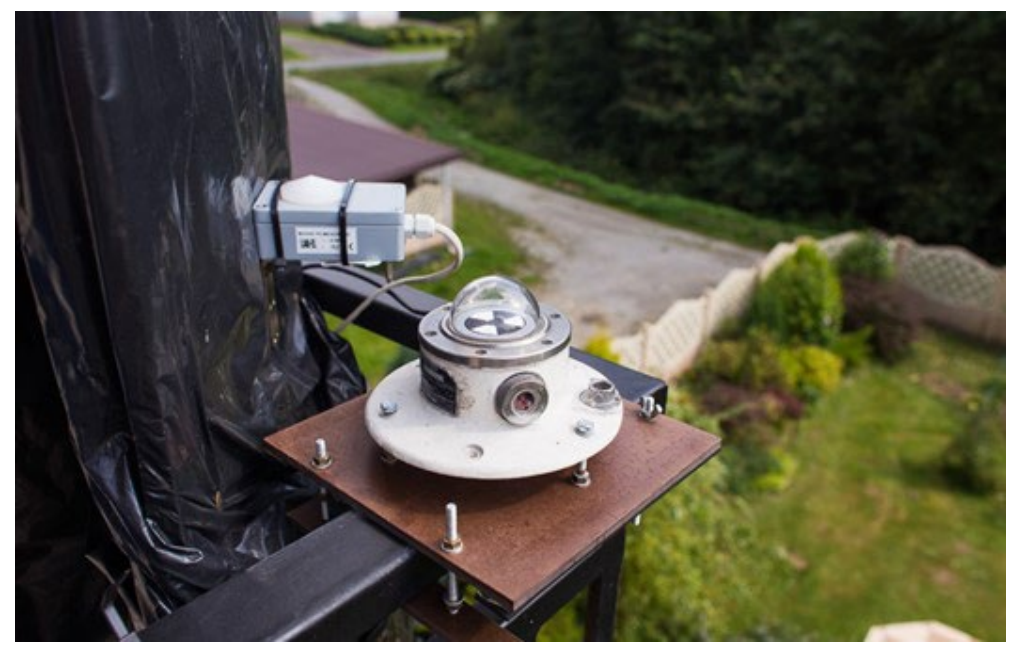

Fig. 4. Setting up the solar radiation meter in the building where the installation has been working Source: own study

Rys. 4. Ustawienie miernika natężenia promieniowania słonecznego w budynku, w którym pracowała instalacja 
The operating conditions (registered) of the installation in the selected 2 days are shown in Figure 5.

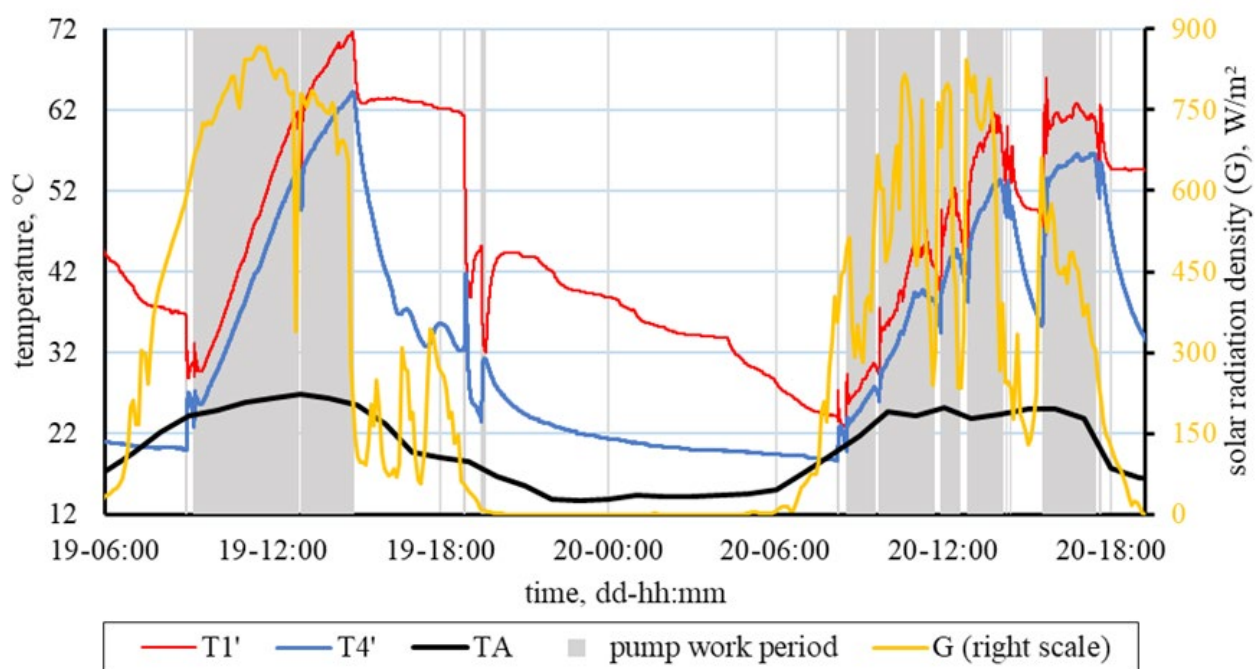

Fig. 5. Measurement results for the selected two days of analysis, June 2015

Source: own study

Rys. 5. Wyniki pomiarów wybranych podczas 2-dniowej analizy, czerwiec 2015

The following characteristic installation periods were selected for detailed analysis:

$\downarrow$ first start of the cycle during the day,

$\uparrow$ continuous work,

$\downarrow$ stopping the circulation,

$\downarrow$ work after sunset.

The ratio of solar heat energy supplied to the domestic hot water storage tank to the measured insolation was $34 \%$.

\subsection{First daily circulation start}

The results of measuring the temperature and the period of operation of the circulation pump associated with the first (morning) start of the installation circuit are shown in Figure 6.

At the moment when the value of temperature measured near the outlet from the collector ( $T 1$ ) exceeded by a set minimum dT_on $(9 \mathrm{~K})$ the value measured in point $T 2$, the automation switches on the pump circuit and the fluid begins to circulate in the installation. Dividing the distance between the collectors and the hot water tank, the fluid overcomes in less than 1 minute, 


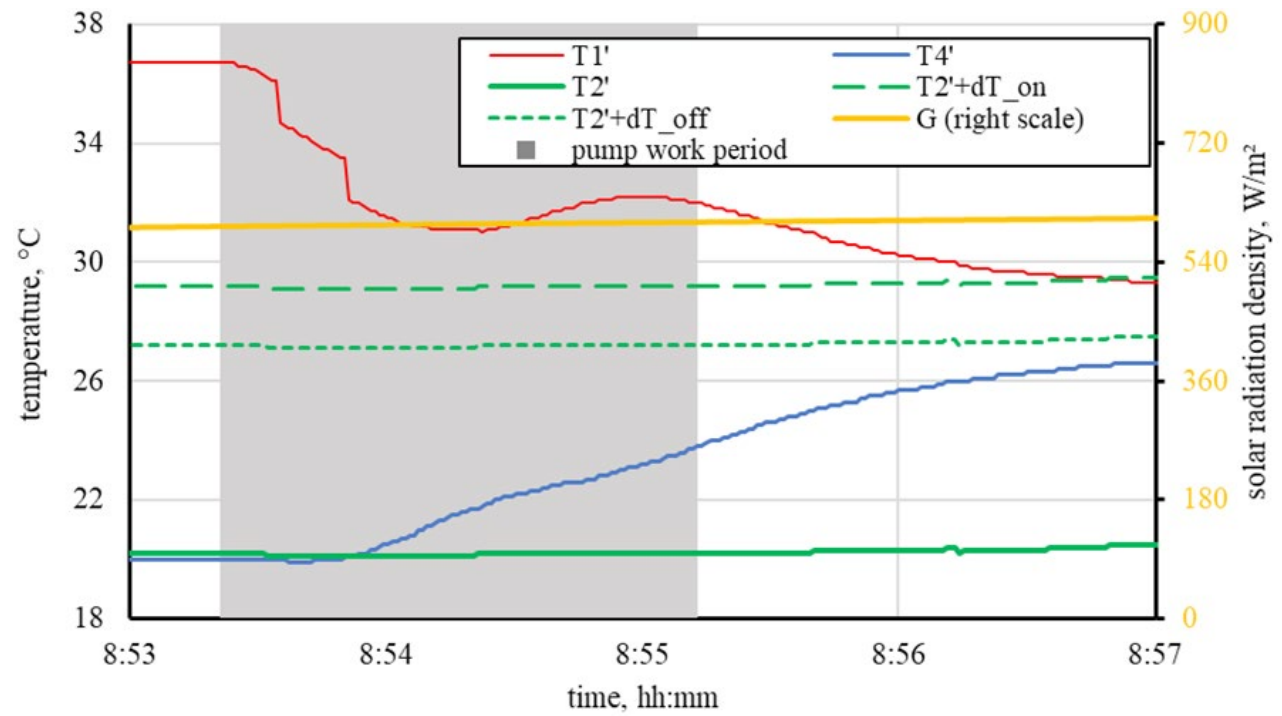

Fig. 6. The first start of the installation's operation on May 19, 2015

Source: own study

Rys. 6. Pierwszy start pracy pompy obiegowej dnia 19.05.2015

however, due to the contact method of mounting the thermometer, an additional time delay has been observed (change in the graph after more than a minute - for $T 1^{\prime}$ ).

Observing the flow temperature measured at the storage tank $\left(T 1^{\prime}\right)$, it can be seen that first gravity heated fluid flows (noticeable difference between $T 1$ and $T 4$ during stops) from the domestic hot water storage tank. Then, for some time, the liquid cooled during the night (depending to some extent on the TA and THI values) flows until warmer fluids from the collectors begins to flow (about 08:54:30). During this initial time, the heat gain is counted (in TVM method), although only part of the heat lost at night actually returned to the tank. In the calculation of heat gain, the controller took took into account the temperature difference, the minimum values of which are presented in Figure 6, the actual value is greater, but dT (taken into account by the controller in the calculations) is difficult to determine with the used measuring devices, because of the temperature in point $T 1$. At the time of starting the pump circuit, it was at least the required value dT_on, i.e. 9, and at the end of the pump operation dT_off $=7$.

Considering the above, for a total of nearly two minutes of pump operation, the calculations according to equation 3 (TVM) of solar heat gains $\left(Q_{S T}\right)$ were higher than those calculated by the controller. One of the reasons is that at the time of starting the pump, the solar fluid, which needs time to flow close to one minute and it does not actually supply solar energy in the form of heat to the storage tank. At the time of start:

$\downarrow$ the controller includes $\mathrm{dT}=9 \mathrm{~K}$, because $T 2^{\prime}$ was equal to $T 4^{\prime}$,

$\checkmark$ the temperature method (TVM) $T 1^{\prime}-T 4^{\prime}=20 \mathrm{~K}$. 
At the moment of work stop, both methods take a similar temperature difference into account, respectively 7 and $8 \mathrm{~K}$.

In summary, the first daily commissioning of the installation is associated with inaccurate calculation of heat gains (for a period of at least one minute). In the case of calculations carried out by the main controller, the reason for the discrepancy is the failure to take the liquid cooled overnight in the installation connecting the tank with the collectors into account. For the temperature verification method (TVM), the recorded amount solar heat gains is influenced by the value of heat gravitationally losses from the hot water tank through solar fluid inside pipe which connect the HWT with the solar collector.

The analysis of the installation's operation during start-up allows the lack of by-bass preventing the storage tank from cooling by the colder inflowing fluid to be determined. It was found possible to improve (higher solar gains) in the form of changing the method of connecting pipes to the HWT in a way that prevent the gravitational cooling of the tank by the fluid (when pump doesn't work). However, these solutions should be analyzed in terms of economic costs, because e.g. the estimated effect of using a by-pass in the form of additional energy obtained will reach a maximum of several $\mathrm{MJ}$ per year.

\subsection{Solar circuit operation}

The periods with the greatest impact on the calculation of heat yields are the periods of virtually continuous operation of the installation. Examples of such periods are: May 19 between 9 am and 3 pm and several periods between 9 am and 6 pm, on May 20.

Due to the long duration of the pump work, calculations based on measurements have a large impact on the achieved results. There are at least two reasons for this:

$\checkmark$ linear losses along the length of the supply pipeline associated with the supply temperature HWT (T1) and the environment affected by THI and G, the unheated attic heats up due to high values of solar irradiance. These losses can range from a few to several \% of gains depending on external conditions and length (Roberto et al. 2010),

$\checkmark$ method of measurement: at the outlet from the collector, the sensor is inserted inside into a special measuring sleeve, and at the tank on the return under the cover on the pre-insulated pipe.

\subsection{Circulation stop after work period}

Another of the typical periods of system operation is the moment of switching off the circulation pump. During the period under study, several such events occurred, one of them has been selected for detailed analysis, since it occurred after a long operation of the circulating pump and 
before a several hours break. The reason for stopping the work of the circuit was a decrease in the intensity of solar radiation with simultaneous high operating parameters of the system negatively affecting the achieved efficiency (surplus over the ambient temperature), recorded measurements are shown in Figure 7.

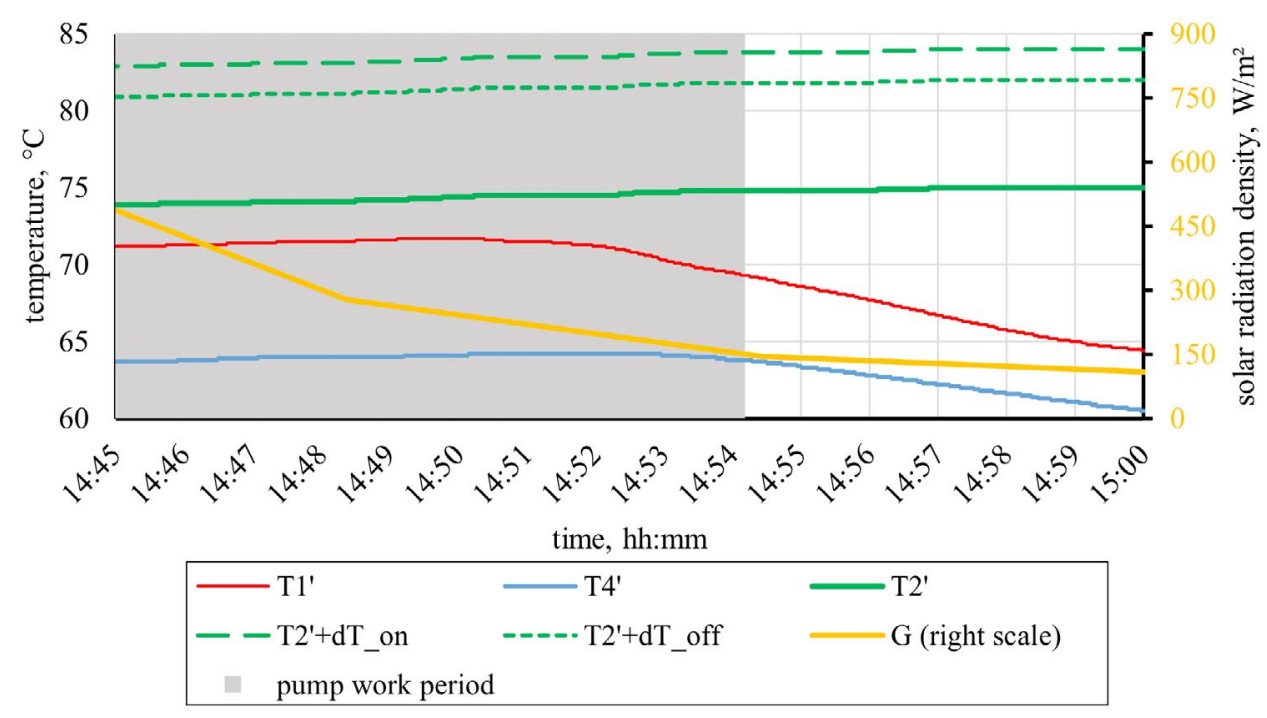

Fig. 7. Afternoon stop of the solar circuit pump operation (May 19, 2015) Source: own study

Rys. 7. Popołudniowe zatrzymanie pracy obiegu (19.05.2015)

Around 2:54 pm the temperature difference measured between $T 1$ and $T 2$ fell below the programmed value ( $\mathrm{dT}<\mathrm{dT}$ _off) and the pump circuit was switched off. However, the solar fluid was left along the entire length of the supply pipe $(15 \mathrm{~m})$, the temperature of which at the moment of leaving the collectors met the condition $>(\mathrm{dT}$ _off $+\mathrm{T} 2)$. Heat transported by the fluid was included as heat gain (by the controller), although it did not reach the tank. In addition, due to the decidedly higher temperature of the fluid from TA and THI, heat was lost from the fluid by transfer from both supply and return pipes.

\subsection{Circulation operation after the disappearance of solar radiation}

A less typical event during the operation of the installation, but which may occur especially on days with high sun exposure, is the temporary start of the pump cycle in the evening, when the intensity of solar radiation is already close to zero (Fig. 8). This results from the accumulated 
heat in collectors and pipes and the consumption of hot water by users, which causes a decrease in $T 2^{\prime}$ measured in the tank. The temperature measured at $T 1$ slowly decreased due to losses to the environment, and for $T 2^{\prime}$ there was a rapid decrease due to the inflow of cold water (as a result of DHW intake by users) and losses to the environment, which is why dT increases (leading to the activation of the circulation pump).

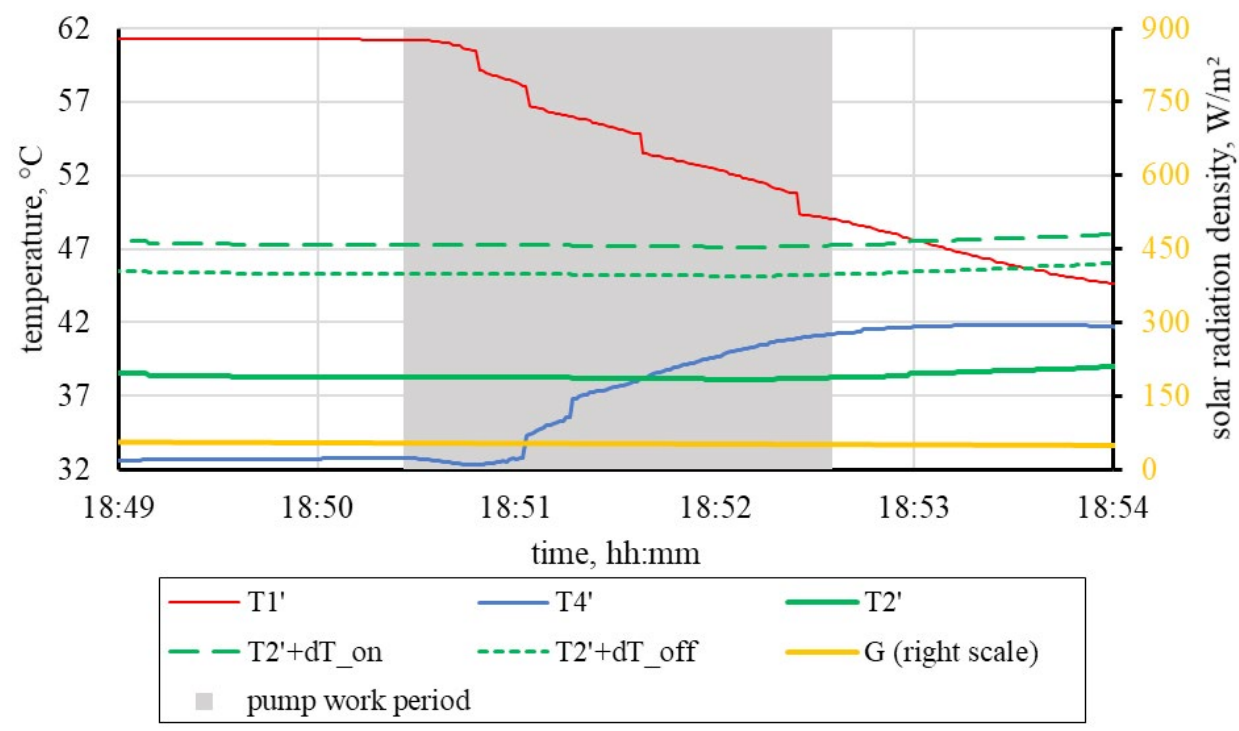

Fig. 8. Measurements recorded during the evening operation of the collector's installation (May 19, 2015) Source: own study

Rys. 8. Zarejestrowane pomiary podczas wieczornej eksploatacji instalacji kolektorów (19 Maj 2015)

At the start of circuit, it can be seen $\mathrm{dT}^{\prime}$ around $23 \mathrm{~K}$, and the controller always switches on the circuit at dT equal to $9 \mathrm{~K}$, however, in connection with the data presented in Figure 6, the increased gains in this case result from the heat accumulated in the pipes, which came from the solar collectors. The observed situation has been different from the start-up observation, where the warmer factor has been accumulated in the piping only near the tank.

\subsection{Daily results}

Differences in solar gain measurements between the PLUM and TVM methods are shown in Table 3. 
TABLE 3. Differences in measurements results according to PLUM and TVM and the value of measured solar insolation

TABELA 3. Różnice w wynikach pomiarów według PLUM i TV oraz wartość zmierzonego nasłonecznienia

\begin{tabular}{|l|c|c|c|}
\hline \multicolumn{1}{|c|}{ Parameter } & Unit & 19 May & 20 May \\
\hline$Q_{S}$ according to the controller (PLUM) & $\mathrm{kWh} /$ day & 12.1 & 12.8 \\
\hline$Q_{S T}$ according to the proposed verification method (TVM) & $\mathrm{kWh} /$ day & 14.39 & 14.87 \\
\hline I (Insolation per collector area) & $\mathrm{kWh} /$ day & 33.7 & 27.4 \\
\hline I (Insolation) & $\mathrm{kWh} /\left(\mathrm{m}^{2} \cdot\right.$ day $)$ & 6.01 & 4.89 \\
\hline Difference & $\%$ & 19 & 16 \\
\hline
\end{tabular}

Source: own work.

\section{Conclusions}

For the installation consisting of 3 solar collectors supporting preparation of hot utility water for a single-family residential building, the characteristic moments of the system operation and their impact on the measurement of heat supplied to the hot water tank have been analyzed. The detailed analysis concerned days with high solar heat gains compared to the average heat demand for hot water production in the building $(7.3 \mathrm{kWh} /$ day $)$. The check was carried out at a daily insolation value higher than $4.8 \mathrm{kWh} / \mathrm{m}^{2}$ measured on a horizontal plane.

The verification temperature method (TVM) of the calculated gains by the solar system controller (PLUM) has been proposed. Then, differences in measurements according to two methods (controller and TVM) have been presented at various characteristic moments of the installation's operation (start-up, stop) as well as during continuous operation. It has been shown that during the day solar heat gains measured by the controller can be $15 \%$ lower than solar heat gains measured by the TVM method (based on Case Study). The sum of the annual solar heat gains measured by the controller and TVM differed by $5.2 \%(+/-1.9$ percent point $)$.

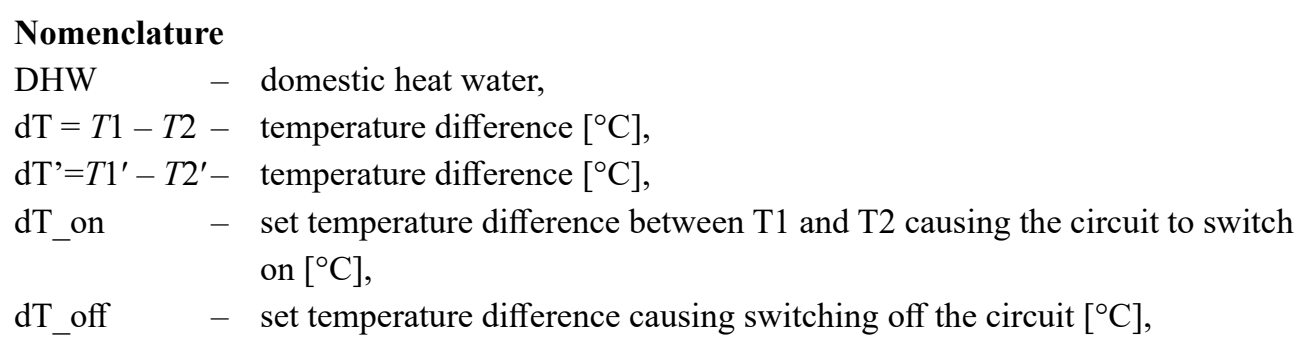




\begin{tabular}{|c|c|}
\hline HWT & - hot water tank, \\
\hline PLUM & - name of automation system in solar installation, \\
\hline$Q_{S}$ & - solar heat gains measured by the controller PLUM [kWh], \\
\hline$Q_{S T}$ & - solar heat gains measured by TVM [kWh], \\
\hline SHF & - solar heat fluid \\
\hline$T 1$ & - temperature of the liquid coming out from the solar collectors $\left[{ }^{\circ} \mathrm{C}\right]$, \\
\hline$T 1^{\prime}$ & - temperature of fluid entering the tank $\left[{ }^{\circ} \mathrm{C}\right]$, \\
\hline$T 2$ & - temperature measured in HWT (bottom part) $\left[{ }^{\circ} \mathrm{C}\right]$ \\
\hline$T 4$ & $\begin{array}{l}\text { - return temperature from HWT to collectors (measured by the controller) } \\
{\left[{ }^{\circ} \mathrm{C}\right] \text {, }}\end{array}$ \\
\hline$T 4^{\prime}$ & $\begin{array}{l}\text { - return temperature from HWT to collectors (through the meter PROVA) } \\
{\left[{ }^{\circ} \mathrm{C}\right],}\end{array}$ \\
\hline TA & - outside temperature $\left[{ }^{\circ} \mathrm{C}\right]$ \\
\hline THI & - temperature inside building $\left[{ }^{\circ} \mathrm{C}\right]$ \\
\hline TVM & - temperature verification method. \\
\hline
\end{tabular}

\section{References}

Al-Shamani et al. 2017 - Al-Shamani, A.N., Sopian, K., Mat, S. and Abed, A.M. 2017. Performance enhancement of photovoltaic grid-connected system using PVT panels with nanofluid. Solar Energy 150 , pp. 38-48.

Baccoli et al. 2018 - Baccoli, R., Frattolillo, A., Mastino, C., Curreli, S. and Ghiani, E. 2018. A comprehensive optimization model for flat solar collector coupled with a flat booster bottom reflector based on an exact finite length simulation model. Energy Conversion and Management 164, pp. $482-507$.

Biawar 2015. Hevelius wunder. [Online] http://www.biawar.com.pl/systemy-solarne/hevelius-wunder-kolektory-plaskie/hevelius-cls-3-bz [Accessed: 2020-01-04].

Boryszewerg 2020. Ergolid A. [Online] https://www.boryszewerg.com.pl/produkty/plyny-do-instalacji/ergolid-a/ [Accessed: 2020-04-10].

Dayamand et al. 2020 - Dayamand, A., Aykapadathu, M., Sellami, N. and Nazarinia, M. 2020. Experimental Investigation of a Novel Absorptive/Reflective Solar Concentrator: A Thermal Analysis. Energies 13(5), p. 1281.

EPLAB 2015. Black \& White Pyranometer. [Online] http://www.eppleylab.com/wp-content/uploads/pdf/ EPPLEY160919-8-48-Diffuse.pdf [Accessed: 2020-01-05].

Fiaschi et al. 2019 - Fiaschi, D., Manfrida, G., Petela, K. and Talluri, L. 2019. Thermo-electric energy storage with solar heat integration: Exergy and exergo-economic analysis. Energies 12(4), p. 648.

Figaj et al. 2019 - Figaj, R., Szubel, M., Przenzak, E. and Filipowicz, M. 2019. Feasibility of a small -scale hybrid dish/flat-plate solar collector system as a heat source for an absorption cooling unit. Applied Thermal Engineering 163, p. 114399.

Jeleński et al. 2020 - Jeleński, T., Dendys, M., Tomaszewska, B. and PajĄK, L. 2020. The Potential of RES in the Reduction of Air Pollution: The SWOT Analysis of Smart Energy Management Solutions for Krakow Functional Area (KrOF). Energies 13, p. 1754. 
KATSAPRAKAKIS, D.A. and ZidianAKIS, G. 2019. Optimized Dimensioning and Operation Automation for a Solar-Combi System for Indoor Space Heating. A Case Study for a School Building in Crete. Energies 12(1), p. 177.

KNAPIK, M. 2018. Analysis and comparison of methods for the preparation of domestic hot water from district heating system, selected renewable and non-renewable sources in low-energy buildings. E3S Web of Conferences 30, p. 03001.

Kryzia, D. and PePŁowska, M. 2019. The impact of measures aimed at reducing low-stack emission in Poland on the energy efficiency and household emission of pollutants. Polityka Energetyczna - Energy Policy Journal 22(2), pp. 121-132, DOI: 10.33223/epj/109912.

Lee et al. 2020 - Lee, M., Shin, Y. and Chо, H. 2020. Performance Evaluation of Flat Plate and Vacuum Tube Solar Collectors by Applying a MWCNT/Fe3O4 Binary Nanofluid. Energies 13(7), p. 1715.

Mirowski, T. and Sornek, K. 2015. Potential of prosumer power engineering in Poland by example of micro PV installation in private construction (Potencjat energetyki prosumenckiej w Polsce na przyktadzie mikroinstalacji fotowoltaicznych $w$ budownictwie indywidualnym). Polityka Energetyczna - Energy Policy Journal 18(2), pp. 73-84 (in Polish).

Montoya-Marquez, O. and Flores-Prieto, J.J. 2017. The effect of the angle of inclination on the efficiency in a medium-temperature flat plate solar collector. Energies 10(1), p. 71.

Montoya-Márquez, O. and Flores-Prieto, J.J. 2018. Heat removal factor in flat plate solar collectors: Indoor test method. Energies 11(10), p. 2783.

OcŁoń et al. 2020 - OcŁoń, P., Cisek, P., Kozak-Jagiela, E., Taler, J., Taler, D., Skrzyniowska, D. and FEDORCZAK-CisAK, M. 2020. Modeling and experimental validation and thermal performance assessment of a sun-tracked and cooled PVT system under low solar irradiation. Energy Conversion and Management 222, p. 113289.

OlCZAK, P. 2020a. The influence of excessive solar heat gains on heat loss in the hot water tank - case study. Polityka Energetyczna - Energy Policy Journal 23(2), pp. 91-104, DOI: 10.33223/epj/122620.

OLCZAK, P. 2020b. The comparison of solar installation heat gains and SHW simulation results - case study. Polityka Energetyczna - Energy Policy Journal 23(3), pp. 41-54, DOI: 10.33223/epj/126981.

OlczaK, P. and Kryzia, D. 2016a. Profitability of Using Solar Collectors for Modernized Domestic Hot Water Installation in Single-Family House (Optacalność zastosowania kolektorów słonecznych w modernizowanej instalacji ciepłej wody użytkowej domu jednorodzinnego). Cieplownictwo, Ogrzewnictwo, Wentylacja 47(3), pp. 94-99 (in Polish).

Olczak, P. and Kryzia, D. 2016b. Analysis of Possible Use of Solar Tracking Mirror Collectors in Polish Conditions and Selection of Their Arrangement (Analiza możliwości wykorzystania lustrzanych kolektorów nadąznych $w$ warunkach polskich oraz wybór sposobu ich rozmieszczenia). Ciepłownictwo, Ogrzewnictwo, Wentylacja 47(7), pp. 259-264 (in Polish).

Olczak, P. and Olek, M. 2016. Limiting classic smog through the use of flat solar collectors (Ograniczenie smogu klasycznego poprzez zastosowanie płaskich kolektorów słonecznych). Odnawialne Źródła Energii i Gospodarka Odpadami Oraz Ochrona i Gospodarowanie Zasobami Przyrody - Wybrane Problemy w Polsce, PWSZ Tarnów, Tarnów, pp. 83-96 (in Polish).

OlczaK, P. and Zabaglo, J. 2015. The Efficiency of the Solar System With Heat Pipe Collectors in Apartment Building. District Heating, Heating, Ventilation 11(46), p. 427.

OlczaK et al. 2015 - OlczaK, P., Zabaglo, J., Kandefer, S. and DziedZic, J. 2015. Influence of Solar Installation with Flat-Plate Collectors in a Detached House on Pollutants Emission and Waste Stream. Between Evolution and Revolution - in Search of an Energy Strategy, WAT, Poznań, pp. 739-752.

OlczaK et al. 2017a - OlCZaK, P., KrYzia, D. and OleK, M. 2017. Cost-effective use of the rack in a solar installation - case study (Ekonomiczna efektywność zastosowania stelaża w instalacji solarnej - studium przypadku). Ciepłownictwo, Ogrzewnictwo, Wentylacja 48(8), pp. 331-334 (in Polish). 
Olczak et al. 2017b - Olczak, P., Porzuczek, J. and Kandefer, S. 2017. Passive sun tracking of a single evacuated tube collector with the focusing mirror. 2016 IEEE International Conference on Power and Renewable Energy, ICPRE 2016, pp. 611-615.

Olczak et al. 2018 - Olczak, P., Kryzia, D., Augustyn, A. and Olek, M. 2018. The economic profit-ability of the changing size of solar collectors surface in the case study of the household domestic hot water installation (Opłacalność ekonomiczna zmiany wielkości powierzchni kolektorów stonecznych ptaskich w instalacji c.w.u. budynku jednorodzinnego - studium przypadku). Zeszyty Naukowe Instytutu Gospodarki Surowcami Mineralnymi i Energia PAN 102, pp. 77-90 (in Polish).

Olczak et al. 2019 - Olczak, P., Kryzia, D., Matuszewska, D. and Halbina, A. 2019. Analysis of financial risk of a hard coal mine participation in DSR mechanisms in Poland - A case study. E3S Web of Conferences, DOI: 10.1051/e3sconf/201912301005.

OlczaK et al. 2020a - OlczaK, P., Matuszewska, D. and Zabaglo, J. 2020. The Comparison of Solar Energy Gaining Effectiveness between Flat Plate Collectors and Evacuated Tube Collectors with Heat Pipe: Case Study. Energies 13(7), p. 1829.

OlczaK et al. 2020b - OlcZaK, P., Olek, M. and Kryzia, D. 2020. The ecological impact of using photothermal and photovoltaic installations for DHW preparation. Polityka Energetyczna - Energy Policy Journal 23(1), pp. 65-74, DOI: 10.33223/epj/118999.

Olek et al. 2016 - Olek, M., OlczaK, P. and Kryzia, D. 2016. The sizes of Flat Plate and Evacuated Tube Collectors with Heat Pipe area as a function of the share of solar system in the heat demand. E3S Web of Conferences 10, p. 00139.

PORZUCZEK, J. 2016. A novel approach for the design of the modular controllers for solar thermal systems A Novel Approach for the Design of the Modular Controllers for Solar Thermal Systems 1, pp. 79-86.

Roberto et al. 2010 - Roberto, B., Ubaldo, C., Stefano, M., Roberto, I., Elisa, S. and Paolo, M. 2010. Graybox and adaptative dynamic neural network identification models to infer the steady state efficiency of solar thermal collectors starting from the transient condition. Solar Energy, DOI: 10.1016/j. solener.2010.03.011.

Sarafraz et al. 2019 - Sarafraz, M.M., Tlili, I., Baseer, M.A. and Safaei, M.R. 2019. Potential of solar collectors for clean thermal energy production in smart cities using nanofluids: Experimental assessment and efficiency improvement. Applied Sciences (Switzerland) 9(9), p. 1877.

Weiss, W. and SPÖRK-Dür, M. 2018. Global Market Development and Trends in 2018. Gleisdorf, Austria.

Piotr OLCZAK

\section{Metoda temperaturowej weryfikacji solarnych uzysków ciepła w instalacji z kolektorami płaskimi - studium przypadku}

\section{Streszczenie}

W budownictwie jednorodzinnym coraz częściej stosuje się kolektory słoneczne. Ich popularność zależy od wielu czynników, w tym stosunku ceny do wydajności, co z kolei wynika z rozwoju technologii 
kolektorów słonecznych, a także całych systemów. Na rozwój ten składa się wiele aspektów, w tym związanych z modernizacją układów sterowania i pomiarami systemów kolektorów słonecznych. Obecnie stosowane systemy oferują m.in. możliwość określenia przybliżonych uzysków ciepła słonecznego za pomoca czujników niezbędnych do normalnego sterowania układem pracy systemu. W artykule przeanalizowano, na przykładzie jednego obiektu, jak takiego typu instalacje działają w polskich warunkach. Do analizy wybrano instalację składającą się z 3 kolektorów słonecznych wspomagających przygotowanie ciepłej wody użytkowej dla budynku mieszkalnego jednorodzinnego. Szczegółowa analiza dotyczyła dni z dużymi uzyskami ciepła w porównaniu ze średnim zapotrzebowaniem na ciepło do przygotowania ciepłej wody w budynku. Zaproponowano metodę weryfikacji temperatury (TVM) obliczonych zysków ciepła słonecznego przez regulator systemu solarnego. Następnie przedstawiono różnice w pomiarach prowadzonych dwiema metodami (sterownik PLUM i TVM) w różnych charakterystycznych momentach pracy instalacji (rozruch, zatrzymanie) oraz podczas pracy ciągłej. Wykazano, że w ciągu dnia uzyski ciepła mierzone przez kontroler mogą być o 15\% niższe niż uzyski mierzone metodą TVM. Sprawdzenie zostało przeprowadzone przy dziennej wartości nasłonecznienia wyższej niż $4,8 \mathrm{kWh} / \mathrm{m}^{2}$ mierzonego w płaszczyźnie poziomej. Stosunek energii cieplnej dostarczonej do zasobnika ciepłej wody użytkowej do zmierzonego nasłonecznienia wyniósł 34\%. Suma rocznych uzysków ciepła słonecznego mierzonych przez regulator i TVM różniła się o $5,2 \%$.

SŁOWA KLUCZOWE: pomiary, energia słoneczna, kolektory słoneczne termiczne, źródła energii słonecznej, pomiar efektywności energetycznej 